\title{
Francophone Minority Identities and Language Rights in Canada*
}

\author{
Mike Ponting, University of Alberta \\ Department of Political Science, M.A. Candidate
}

While phrases such as 'Capitaine Crounche' and 'beurre d'arachide' are familiar to, and easily taken for granted by, most English Canadians, who tend to encounter linguistic duality in their daily lives in a number of ways, the politics underlying such seemingly harmless words are significant. Indeed, no other issue has played as central a role in Canadian social and political development as has language, with French-English linguistic tensions and considerations affecting numerous aspects of Canadian life, including foreign policy, the awarding of government contracts and indeed, the labelling of food packaging. While much public and scholarly attention has been paid to the language issue and the francophone population of Québec, less has been paid to language and francophones outside of the main concentration of Canada’s French speakers. While geographically dispersed, and vastly outnumbered, Canada’s francophone minority communities and their identities are nevertheless an important part of the Canadian social fabric, as is evidenced by the amount of government attention these French Canadians ${ }^{1}$ receive. Two key developments in the collective identity of francophone minorities

\footnotetext{
* I wish to thank Yasmeen Abu-Laban (for whose class this paper was originally written) for her comments and suggestions. Any errors or omissions are entirely my own.

${ }^{1}$ For the purposes of this essay, francophone minorities, non-Québec francophones, French Canadians, etc. will include all of those of French mother tongue, home language, or first official language, living outside of Québec. Although the term 'Acadian' is perhaps more proper and sensitive to the distinctiveness of French Canadians of the Maritimes, for purposes of simplicity, in this essay, they will be included among the other appellations listed above. As well, in general, I will use the above phrases to describe francophones from outside Québec, and 'Québecois' to describe those from within the province, rather than risk confusion about the term 'French Canadians' (itself a controversial element of the identity debate).
} 
occurred in 1969 and 1982, when the Official Languages Act (OLA), and the Canadian Charter of Rights and Freedoms were (respectively) promulgated, the latter including constitutionally entrenched language rights for official language minorities. In this essay, we will examine the vitality of francophone minority communities, and how language rights have impacted them and contributed to the maintenance of their identity. Specifically, we will argue that minority francophone communities are still strong and that language rights have reinforced these communities and their identities, and have made an important contribution to their survival and long-term vitality. It is hoped that gaining a more complete understanding of the impact of language rights on these groups will not only provide a fuller understanding of French Canadian identity, but also of identity in Canadian society in general.

\section{Major Developments in French Canadian Identity and Language Rights}

In order to gain a complete understanding of the circumstances that led to the recognition of language rights for French Canadians, we must look back over 200 years to witness the contextual and historical factors that led to the creation of francophone communities in English Canada, and to the creation of statutory and constitutional rights to ensure their survival. Therefore, in this section, we will examine many of the important related historical events, so that the current context of rights will be more easily comprehensible. This is not intended to be an exhaustive list, but rather a cursory overview of several of the most relevant events.

For over a century prior to the conquest of 1763, France had established colonies and trading networks throughout much of the known new world of America (with the exception of the thirteen English colonies along the eastern seaboard). The government of France sent thousands of people to the new world to establish a colonial society which was most developed in what are today the Maritimes, and the province of Québec. While Québec and Montreal were 
the major urban centres of France’s American colony, many thousands of French speaking colonists also lived in parts of modern-day New Brunswick, Prince Edward Island, and Nova Scotia. These people became known as the Acadians.

During much of the eighteenth century, France and England were at war, and with the signing of the Treaty of Utrecht in 1713 to end one of these wars, the Acadians found themselves under British rule. ${ }^{2}$ At war with France again in the 1750s, the British demanded that the Acadians swear loyalty to the British crown. The Acadians refused, however, insisting on remaining neutral in the conflict. This refusal led to their deportation from their homeland in Acadia between 1755 and 1763, a major landmark in the history of the Acadian people, and a key formative event in the Acadian identity. ${ }^{3}$ After the Treaty of Paris, which ended yet another war between France and England in 1763, the Acadians were permitted back in their traditional homeland, though they were relegated to the fringes of the land they once inhabited. ${ }^{4}$ However, those Acadians who survived the deportation are the descendents of the modern Acadian community, which is one of Canada's largest and most concentrated French Canadian communities. With a history and social development quite distinct from their Québecois colinguists, the Acadians are a separate community with a unique identity living as a minority in the Maritimes.

There are other francophone groups in other majority English provinces in Canada as well. For example, in the late nineteenth century, the lack of available seigneurrial land in Québec sent a number of francophones into Ontario. There, many found employment in the province's booming forestry industry, and later in other industries such as mining, and pulp and

\footnotetext{
${ }^{2}$ Pierre A. Coulombe. Language Rights in French Canada. ( New York: Peter Language Publishing Inc., 1997), 83.

${ }^{3}$ Ibid.

${ }^{4}$ Robert A Stebbins. The French Enigma: Survival and Development in Canada's Francophone Societies. (Calgary: Detselig Enterprises Ltd., 2000), 44.
} 
paper. $^{5}$ As a result, significant pockets of French Canadians with a strong identity and collective memory can be found in Ontario’s eastern region (Ottawa), north west region (Sudbury, North Bay), and south west region (Windsor).

A number of Québecois colonists and voyageurs moved further west, including a number who would marry native women, particularly in what would later become the province of Manitoba. The children of these mixed Québecois-Indian marriages became a new categorization of French Canadian called Métis, who contributed much to the development of French Canadian society and identity on the prairies. ${ }^{6}$ Also in western Canada, a number of Québecois homesteaders moved to underdeveloped parts of the 'Northwest Territory.' In search of abundant and inexpensive land, and often encouraged by the Catholic church, these homesteaders established small francophone colonies throughout the west, such as St. Paul, Alberta. ${ }^{7}$ In doing so, they formed another integral component of the French Canadian identity outside Québec.

As a result of the development of all these communities, there are now francophone communities in every province and territory in Canada. These francophone societies have demonstrated a great degree of strength and resilience, which, has resulted in a strong francophone minority identity from coast to coast in Canada. However, due to their lack of numerical strength and an often hostile English majority surrounding them, these francophone communities have often been very volatile and have faced assimilation by the majority English community.

Language rights in Canada have a similarly long history. After the conquest of Québec

\footnotetext{
${ }^{5}$ Ibid., 48-50.

${ }^{6}$ Ibid., 51-2.

${ }^{7}$ Aunger, Edmund A. "The Decline of a French-Speaking Enclave: A Case Study of Social Contact and Language Shift in Alberta.” Canadian Ethnic Studies 25 (1993), 67.
} 
was formally completed in 1763, the plan of the British government was to assimilate all French speaking colonists into British society in America. However, political expediency necessitated tolerance of these colonists before and during England's war to prevent the thirteen American colonies from gaining independence. As such, in the Quebec Act of 1774, while there were technically no language rights, the religion and legal system of the Québecois were legally recognized. ${ }^{8}$ However, with Britain’s loss of the American war of independence, thousands of loyalist settlers arrived in the traditionally French colonies such as Québec and Nova Scotia, which soon resulted in Acadians being outnumbered by anglophones in the latter. To accommodate this influx of anglophones, the territory of Québec was divided into two colonies (upper and lower Canada), and a new colony, New Brunswick, was created in the Maritimes where the majority of Acadians lived (although as a minority). Significantly, the Constitutional Act of 1791 (the Act which partitioned Québec) further legalized French in Lower Canada, though English was still the official language of the colony. ${ }^{9}$

However, with two linguistic communities, tensions soon heightened in the Canadas. After unsuccessful rebellions in both of the Canadian colonies, the uniting of the Canadas in order to assimilate the French speaking colonists, and political deadlock in the Canadian assembly, three of England's North American colonies decided to adopt a new strategy. The Canadas, New Brunswick and Nova Scotia united in 1867 to form the Dominion of Canada. This new country was created as a federation, with French speaking Québecois forming a majority within the new province of Québec, and with provincial legislatures having constitutional control over such key cultural matters as education, and civil law. Of great importance in Canada's new constitution (now known as the Constitution Act, 1867) was section

\footnotetext{
${ }^{8}$ Wilfred Denis. “Language Policy in Canada,” in Peter S. Li (ed.) Race and Ethnic Relations in Canada. Second Edition. (Don Mills, Ontario: Oxford University Press, 1999), 181.

${ }^{9}$ Stebbins, 39 .
} 
133 which mandated that English and French could be used in both the federal and Québec Parliaments and courts, and that all laws, records and journals of both would be printed bilingually. ${ }^{10}$ These provisions are Canada's first language rights and were entrenched in Canada's original constitutional pact. Similarly, s. 93 of the constitution (though not technically language rights, per se), mandated that the provinces were obligated to provide denominational schools for the minority religion (language) in each province (i.e. protestant schools in Québec and Catholic schools everywhere else).

As additional provinces and territories were added to the Dominion in the ensuing years, the language provisions of the constitution were extended in several cases. For example, the Manitoba Act of 1870, which admitted that province into confederation, contained s. 23, which provided almost the same linguistic rights as those set out in s. 133 of the Constitution Act, 1867. ${ }^{11}$ This was in large part to accommodate the substantial French speaking Métis community in the province. The strength of this Louis Riel-led community and the favourable terms on which Manitoba was admitted into Canada after a brief Métis rebellion soon formed a key element of the Métis/French Canadian identity in that province. Likewise, in 1875, the Northwest Territory was created as a separate political entity, with Parliament formally making English and French official languages of the territory and establishing language rights similar to s. 133 for the new territory (out of which were later carved the provinces of Alberta and Saskatchewan) two years later. ${ }^{12}$ The granting of these rights was in large part due to the sizeable francophone minority in the territory, particularly in the district of Assiniboia. ${ }^{13}$ The extension of s. 133 rights and other language rights in the west created a sense of optimism

\footnotetext{
${ }^{10}$ Denis, 181.

${ }^{11}$ Ibid., 182.

${ }^{12}$ E.A. Aunger. "Justifying the End of Official Bilingualism: Canada’s NorthWest Assembly and the Dual Language Question, 1889-1892.” Canadian Journal of Political Science, 36 (2001), 458.

${ }^{13}$ Ibid., 459.
} 
among many French speaking Canadians that Canada would be a binational, bilingual country in which French and English would be equal languages, and where French and English Canadian identities could flourish across the country. ${ }^{14}$ However, tolerance for the French language and French Canadians began to erode almost as quickly as language rights had been established in Canada.

The constitutional protection of French Canadian minorities soon came under political attack across English Canada. First, largely in response to "English Canadian jingoism” 15 led by Ontario MP D’alton McCarthy, ${ }^{16}$ Manitoba abolished the official use of French in provincial institutions in 1890 which was a significant blow to the francophone community in that province. ${ }^{17}$ The following year, employing a number of questionable arguments (such as for purposes of national unity ${ }^{18}$ ), the English majority in the Northwest Territory eliminated the printing of French journals and records for the territorial assembly, and followed this move in 1892 by eliminating French schools. ${ }^{19}$

While these restrictions of language rights were the source of controversy in Canada (as was the 1885 hanging of Louis Riel), they were not nearly as controversial as were the restrictions of French language schooling in Ontario. While the legislature of Canada's largest province first restricted the use of French in schools in 1890, Ontario sparked a national constitutional crisis (which was worsened considerably by French Canadian resistance to the Great War) in 1912 with Regulation 17. This regulation made English the only language of

\footnotetext{
${ }^{14}$ Linda Cardinal. “Linguistic Rights, Minority Rights and National Rights: Some Clarifications.” Inroads, Vol. no. 8 (1999), 79.

${ }^{15}$ Aunger (2001)., 477.

${ }^{16}$ Ibid., 452.

${ }^{17}$ Denis, 184.

${ }^{18}$ Aunger (2001), 477.

${ }^{19}$ Ibid., 466. Curiously, however, the territorial Lieutenant-Governor never proclaimed the law eliminating French from the records of the legislature, which led to a linguistic court challenge of English unilingualism nearly a century later. A similar court challenge of the constitutional validity of the Manitoba legislature's unilingualism also took nearly a century to be resolved by the Supreme Court.
} 
instruction in Ontario after grade three, and limited the teaching of French to one hour per day. ${ }^{20}$ This limiting of language education left a lasting impression on the Franco-Ontarian community, and forms an important part of its identity. The battle that ensued over Regulation 17 led to the creation of a number of social organizations and a French language newspaper in the Ottawa area, Le Droit, which have served as important institutions in Ontario’s francophone community. Not to be outdone, Manitoba made English the only language of instruction in its public schools in 1916, and the new province of Saskatchewan followed suit in 1931. With these developments and others, the pan-Canadian character of French Canada was eroded significantly with the result that francophone minority groups had to struggle on their own to maintain their communities and identities in the face of great numerical disadvantage and hostility. ${ }^{21}$

All of these moves against French Canadians' language rights in other provinces (as well as their own economic position vis-à-vis anglophones in their own province) led to a sense of nationalism among francophones in Québec who were determined to take advantage of their majority status within their provincial enclave to avoid similar threats to their own language and identity. ${ }^{22}$ As it was clear that their vision of a tolerant, binational, pluralist society would not be realised in Canada, the Québecois began to reform the institutional structure within their province in order to ensure a homeland for, and the continued survival of, the French Canadian nation within the borders of Québec. ${ }^{23}$ In this revolution tranquille of the 1960s, Quebecers reoriented themselves from a French Canadian identity, to a Québecois identity, and made use of the provincial state to protect and ensure the continued existence and growth of the Québecois

\footnotetext{
${ }^{20}$ Canada: Office of the Commissioner of Official Languages: Our Official Languages: As Century Ends and a Millennium Begins. (Ottawa: Minister of Public Works and Government Services Canada, 2001), 13.

${ }^{21}$ That the federal government did not intervene on behalf of the francophone minorities was the source of great disappointment for many of the minority communities, though less so in Québec, where people were ever mindful of federal intrusions into provincial jurisdiction.

${ }^{22}$ Cardinal, 83.

${ }^{23}$ Ibid.
} 
people. $^{24}$ This was done largely exclusive of their francophone co-linguists in other provinces, resulting in the two groups of francophones now having fundamentally and perhaps permanently distinct identities and constitutional goals. Also, while the French Canadian nation had traditionally defined itself by its ethnicity and Catholic religion, the Québecois now defined themselves by the French language and by the province of Québec. However, as a definitive constitutional entity was not available to non-Québec francophones at this time, their identity continued to rely on the traditional markers of French Canadian identity.

This revolution in the mindset of Quebecers led to a national unity crisis that English Canadians and the federal government could not ignore. Accordingly, in 1963, the Pearson government called the Royal Commission on Bilingualism and Biculturalism (the LaurendeauDunton Commission). ${ }^{25}$ Reporting in 1969, this Commission's findings would have an indelible impact on the future of French Canadians in English provinces and on national language policies for many years to come. Among its recommendations were that Canada adopt language rights. Responding to the findings of the Commission, the Trudeau government passed the first Official Languages Act in 1969. Contrary to the approach favoured by some in Québec, that of 'Territorial Bilingualism’ in which Québec would be French, Ontario and New Brunswick would have s. 133-like language rights, and the rest of Canada would be English, Trudeau adopted the recommendations of the Commission. ${ }^{26}$ He rejected collectivist language rights for communities like English Canada and Québec, opting instead to pursue ‘Personal Bilingualism,’ wherein individuals alone have language rights. According to this line of thinking, English and French

\footnotetext{
${ }^{24}$ Carsten Quell. "Racial, Religious, Ethnic and Linguistic Diversity Intersecting with Canadian Official Language Policies and Communities.” Unpublished (Draft of Paper to be presented at Intersections of Diversity Seminar, Niagara Falls, Ontario, April, 2003), 6.

${ }^{25}$ Office of the Commissioner of Official Languages, 3.

${ }^{26}$ Charles Castonguay. Getting the Facts Straight on French: Reflections Following the 1996 Census, in Inroads, Vol. no. 8 (1999), 67.
} 
would be equal languages for individuals across the country (in federal jurisdiction) and the federal government would promote individual bilingualism. ${ }^{27}$ Trudeau sought to dissociate language from collective identities, making it a personal choice instead. ${ }^{28}$ This strategy was also intended to undermine the collective nature of the Québec nationalist movement.

The OLA mandated that French and English were the official languages of Canada, and that all French and English Canadians have the right to communicate with the federal government in the official language of their choice. ${ }^{29}$ The Act also determined that the federal government would be(come) bilingual, thus allowing itself not only to better provide services to francophones, but also to provide opportunities to French speaking Canadians to speak their native tongue in a working environment. ${ }^{30}$ It was hoped that the creation of a federal government capable of speaking French would counter the tendency of Québecois to feel that the federal government was a foreign government which did not represent their interests and language, and that the Québec government was the only government truly representing Quebecers. In addition, a Commissioner of Official Languages was established to oversee the bilingualization of the federal government, and money was made available to official language minority groups (OLMGs) to assist them in a number of cultural and educational projects, etc. ${ }^{31}$ The Act was updated in 1988 with the federal government making an explicit commitment to "enhanc[e] the vitality of the English and French linguistic minority communities in Canada and supporting and assisting their development...,32

While the language rights of the OLA were a significant new direction for the federal

\footnotetext{
${ }^{27}$ Ibid., 58.

${ }^{28}$ Cardinal, 4.

${ }^{29}$ Denis, 187.

${ }^{30}$ Ibid.

${ }^{31}$ Ibid., $187-8$.

${ }^{32}$ Quoted in Michael O’Keefe. Francophone Minorities: Assimilation and Community Vitality. Second Edition. (Hull, Québec: Department of Canadian Heritage, 2001), 99.
} 
government which it hoped would have an important impact on identities in Canada, Ottawa did much more than the minimum that the Act required. With the threat of Québec nationalism, and, with the election of the separatist Parti Québecois government in 1976, the threat of separatism, the federal government went to even greater lengths. For example, the Trudeau government continually increased its support of OLMGs, gave more money to the Societé Radio Canada (the French language branch of the $\mathrm{CBC}$ ), and provided funding to the provinces for bilingual schooling and services for their OLMGs. ${ }^{33}$ Similarly, Ottawa also set up the Court Challenges Programme to assist OLMGs in litigating against provinces in order to have their minority language rights adequately safeguarded. ${ }^{34}$ The federal government also spends millions of dollars each year for the bilingualization of its own civil service, including expenses like translation, language training, and bilingual bonuses. ${ }^{35}$ Its intention in all of this was to realize Trudeau's vision of pan-Canadian bilingualism in which Canadians from coast to coast have the right and ability to live in either official language, with their identities oriented toward a panCanadian use of official languages among individuals.

Language disputes certainly did not end at this point, however. After a failed sovereignty referendum in Québec in 1980, Prime Minister Trudeau committed his government to substantial constitutional change to solve the national unity crisis. Perhaps misunderstanding Québec’s constitutional needs, perhaps as an effort to undermine those needs, the constitutional amendments agreed upon by the rest of Canada in 1981, including a number of language rights, were not satisfactory to Québec, which has never endorsed the resulting Constitution Act, 1982.

\footnotetext{
${ }^{33}$ Kenneth McRoberts. Misconceiving Canada: The Struggle for National Unity. (Toronto: Oxford University Press, 1997), 92.

${ }^{34}$ F.L. Morton, and Rainer Knopff. The Charter Revolution and the Court Party. (Peterborough: Broadview Press, 2000), 60.

${ }^{35}$ In 1992-3, it spent about \$325 Million. Joseph Elliot Magnet. Official Languages of Canada: Perspectives from Law, Policy and the Future. (Cowansville, Québec. Les Editions Yvon Blais, 1995), 227.
} 
In spite of Québec's objections though, the new Charter of Rights guarantees many of the rights recognized under the OLA and more in ss. 16-23, including the fact that English and French are official languages, that both languages are allowed in federal institutions such as Parliament and federal courts, and that everyone has the right to communicate with the federal government in the official language of their choice, where numbers warrant.

Most controversial about the language rights of the Charter is that it also provides a number of Minority Language Education rights, including the right to have a child educated in the minority official language of a province, if at least one of the child's parents was educated in that minority language anywhere in Canada. This latter provision was in direct conflict with Québec's Bill 101 which determined that parents had the right to educate their children in English only if they had received their education in English in Québec. Significantly, these and all other language rights were left immune from the Charter's 'notwithstanding clause,' so crucial were they to Trudeau's vision. ${ }^{36}$ In spite of Québec’s resistance, the Charter and its language rights apply across Canada, and were intended to assist OLMGs such as minority francophones in all provinces. It should also be noted that a number of additional language rights were entrenched in the Charter for the province of New Brunswick, which sought constitutional permanence for the language rights which protect its Acadian minority.

While francophones in Canada's majority English provinces have endured a number of hardships throughout pre- and post-confederation Canadian history, with the OLA and the language rights of the Charter, Canada's French Canadians now have the most expansive set of rights and protections that they have ever had in Canada. However, there are many who would suggest that this government protection is too little, and far too late, and that the only possible fate for most of Canada's minority francophones is assimilation into the English mainstream.

\footnotetext{
${ }^{36}$ McRoberts, 170.
} 
The impact that language rights have had on these groups and their identities is the question to which we now turn our attention.

\section{The Effects of Language Rights on Canada's Francophone Minority Communities}

While it is without question that the addition of language rights to the constitution and the statute books has significantly changed the linguistic policy climate and legal regime in Canada, whether or not these rights have had their desired effects on OLMGs such as non-Québec francophones is much more difficult to assess. While these rights were intended to have symbolic meaning for francophones in Québec (i.e. a French environment in which to work in the federal government, and a government that responds to French speaking Quebecers in French, etc.), and were intended to benefit the anglophone community of Québec, ${ }^{37}$ minority francophones were a key target as well. Indeed, one of the principle reasons for granting language rights to OLMGs was to strengthen French Canada outside Québec in order to counter the view that Québec is the homeland and only hospitable environment for the French language in Canada. However, as many francophone minority groups have suffered greatly from factors such as geographic isolation, intermarriage and cultural contact with the majority community, the strengthening and providing of additional vitality to francophone groups was not expected to be an easy task. However, it was nonetheless an important one for the nation builders of the federal government.

Before moving into an examination of the effects that language rights have had on francophone minority identities and communities, a number of studies caution us from directly

\footnotetext{
${ }^{37}$ While the Québec anglophone community shares a number of similarities with their minority language cousins in other provinces, in this essay, we are limiting our analysis to francophone minorities, rather than both sets of official language minorities. As a number of key differences exist in the identity and political development of the two minority groups, and as an analysis of the anglophone community in Québec would complicate the issues examined in this paper, I have decided to leave such an analysis out of the present examination.
} 
attributing a rights claimant's newfound vitality or lack thereof to the rights granted in the Charter. For example, as Miriam Smith suggests, the Charter was not necessarily as important a watershed for minority groups as some would suggest. ${ }^{38}$ Smith demonstrates in her analysis of gay rights groups in Canada before 1982 that minority groups drew significantly on the civil rights discourse of the 1960s and 1970s, ${ }^{39}$ and experienced a number of legal victories before the promulgation of the Charter. She suggests that our rights claiming culture predates the Charter, ${ }^{40}$ and that the Charter can often mask the strength of minority groups before its passage. ${ }^{41}$ Similarly, Yasmeen Abu-Laban and Tim Neiguth point to the fact that the Charter strengthened a number of groups (such as ethnic groups and OLMGs) but did not necessarily lead directly to their creation. ${ }^{42}$ They suggest that although its passage was clearly important for a number of groups, many of these groups had considerable strength prior to 1982, and that the Charter's passage was simply one episode in the ongoing struggle of these groups. ${ }^{43}$ With these warnings in mind, we must be careful not to attribute too much to the effects of the Charter, and to be mindful of the strength that francophone minorities had before the passage of the OLA and the Charter.

Looking at the effects of language rights on French Canadian communities, we must first understand that the effects are difficult to assess, and that there has been much disagreement on this issue. Many people suggest that in spite of the new language rights regime in Canada, French Canadian minority communities and identities are continuing an inevitable decline toward assimilation. Among them was former Québec Premier Réné Lévesque who went as far

\footnotetext{
${ }^{38}$ Miriam Smith. “Social Movements and Equality Seeking: The Case of Gay Liberation in Canada," in Canadian Journal of Political Science, 31(2) (1998), 288.

${ }^{39}$ Ibid., 292.

${ }^{40}$ Ibid., 308.

${ }^{41}$ Ibid.

${ }^{42}$ Yasmeen Abu-Laban, and Tim Nieguth. "Reconsidering the Constitution, Minorities and Politics in Canada." Canadian Journal of Political Science, 33(3) (2000), 476.

${ }^{43}$ Ibid., 495.
} 
as to call non-Québec francophones "Dead Ducks." ${ }^{44}$ One of the first scholars to predict the imminent demise of the French language outside a narrow 'bilingual belt' (including parts of Ontario, southern Québec, and northern and eastern New Brunswick) ${ }^{45}$ was Richard Joy. As early as 1971, just two years after the passage of the OLA, Joy forecast an inevitable assimilation for most of Canada's francophone minorities, and argued that French Canadians were 'without hope. ${ }^{46}$ More recently, he has suggested: "it appears clear that, as francophones move away from the Quebec border, they can have little hope of hearing the French language spoken by their grandchildren." ${ }^{47}$

Other writers are equally pessimistic about the survival of Canada's francophone minority identity. One of the most vocal scholarly critics of the Trudeau strategy on official languages and language rights is Kenneth McRoberts. In his book Misconceiving Canada, McRoberts suggests that French Canadians are being increasingly assimilated with each passing census, and that there is little long-term hope for a viable French culture or identity outside Québec. Referring to 1991 census data, he demonstrates that while in 1981, 27.8\% of Canadians outside Québec with a French mother tongue used English more than French at home, in 1991, that number had increased to $34.8 \%$, a remarkable jump in just ten years. ${ }^{48}$ He also indicates that intermarriage (a common phenomenon for non-Québec francophones who are vastly outnumbered by anglophone majorities) has had highly deleterious effects on the French community. In 1991, he argues, while most children outside Québec whose parents are both

\footnotetext{
${ }^{44}$ Claude Couture, and Denis Perreaux. "La Resistance des Francophones des Prairies L'assimilation dans la perspective de la literature moderniste et Postcoloniale.” Francophonie d’Amerique. no 13 (2002), 209.

${ }^{45}$ Aunger (1993), 65.

${ }^{46}$ Quoted in Claude Couture. "La Disparition Inevitable des Francophone a l’Exterieur du Québec: Un Fait Ineluctable ou le Reflet d'un Discours Deterministe?” in Francophonie d'Amerique. no 11 (2001), 8. Translated by the author.

${ }^{47}$ Richard Joy. Canada’s Official Language: The Progress of Bilingualism. (Toronto: University of Toronto Press, 1992), 52.

${ }^{48}$ McRoberts, 103.
} 
francophone had a French mother tongue, if one of a child's parents was an anglophone and one was a francophone, only $13.2 \%$ had a French mother tongue. ${ }^{49}$ McRoberts concludes his analysis of French Canada outside Québec by noting that “overall, people who speak French at home make up 3.2 per cent of the Canadian population outside Québec.”50

These pessimistic forecasts are not limited to anglophone scholars. A prominent francophone demographer, Charles Castonguay, is equally gloomy in his assessment of the longterm viability of Canada's non-Québec francophone communities. Castonguay writes of a “demographic collapse” of French Canada outside Québec, and "staggering intergenerational deficits [of French] outside Québec.."51 He concludes: "the trend toward disappearance is thus already well under way among Canada’s French-speaking minorities outside Québec....”52

Others suggest that language rights specifically have done little to reverse these assimilative trends. Linda Cardinal argues: "it must be admitted that the regime of rights established since the 1960s has not transformed their [French Canadians'] situation in any significant way." 53 Writing about minority language education rights, Joseph Eliot Magnet reaches a similar conclusion: "in most cases, French communities are not being revitalized by minority language education., ${ }^{54}$ He continues: "the Official Languages Policy is unlikely to make significant difference to the future survivability of Canada's official language minorities.”55

With the unfavourable futures predicted by these accomplished scholars in Canadian politics and demography, it could easily be suggested that language rights have not revitalized

\footnotetext{
${ }^{49}$ Ibid., 104.

${ }^{50}$ Ibid., 105.

${ }^{51}$ Castonguay, 61.

${ }^{52}$ Ibid., 62.

${ }^{53}$ Cardinal, 84.

${ }^{54}$ Magnet, 224.

${ }^{55}$ Ibid., 229.
} 
francophone minority communities in Canada. However, a number of researchers are significantly less cynical about French Canada's prospects. Among them, is Claude Couture of the Faculté Saint Jean at the University of Alberta. Writing with Denis Perreaux, Couture states: "we must remember that in western Canada, the population of mother tongue francophones essentially maintained itself at the same numeric level between 1951 and 1996...144 575 people in 1951 to 181046 in 1996." ${ }^{, 56}$ Using words like 'deterministic ${ }^{57}$ and 'alarmist,, ${ }^{58}$ Couture criticises demolinguists for not paying sufficient attention to the nuances of language use when they forecast the death of French Canadian identity. ${ }^{59}$ He also highlights the fact that levels of bilingualism in Canada have increased since $1971,{ }^{60}$ and that the migration of Québecois to Alberta and British Columbia (typically in search of employment opportunities) has helped to sustain minority francophone communities in those provinces. ${ }^{61}$ Couture also points to the salutary effects of "political measures like those of 1969 and of 1982."62

Couture’s colleague at the Faculté Saint-Jean, Edmund Aunger, draws similar conclusions about those who feel that non-Québec francophones are "the walking dead." ${ }^{63} \mathrm{He}$ suggests that an examination of data reveals that francophone communities outside Québec have grown steadily since the first Canadian census in 1871, and that reports to the contrary can sometimes be accounted for by "methodological capriciousness" which "underestimate the

\footnotetext{
${ }^{56}$ Couture and Perraux, 199. Translated by the author.

${ }^{57}$ Ibid., 209.

${ }^{58}$ Couture, 7.

${ }^{59}$ For example, he suggests that a lack of usage of French at home, seen by many to be an hallmark of assimilation, does not necessarily mean that assimilation has taken place. Cultural and linguistic retention go beyond simply the speaking of a language most often at home. Couture, 15-6.

60 Ibid., 11.

61 Ibid., 14.

${ }^{62}$ Ibid., 16. Translated by the author.

${ }^{63}$ Edmund A. Aunger. "Obseques Prematurees: La Disparation des Minorites Francophones et Autres Illusions nationalistes.” Review of Constitutional Studies. Vol. 7, nos. 1 \& 2 (2002), 122. Paraphrased by the author.
} 
importance of the many francophone communities. ${ }^{, 64}$ Aunger also theorizes that many of those predicting the imminent assimilation of francophone minorities are politically motivated, such as the ideologically neo-liberal Reform (now, Canadian Alliance) Party, ${ }^{65}$ as well as nationalists in Québec, who seek "the advancement of their goal of independence for Québec.”66 Furthermore, Aunger demonstrates the economic and cultural vitality of francophone communities outside Québec with numerous statistics and examples proving otherwise, debunking the stereotype that French Canadians are generally rural, uneducated, uncultured, and poorly paid. ${ }^{67}$ Acknowledging the "fragility and vulnerability of the francophone minorities,"68 which cannot be denied, Aunger nevertheless advances a convincing argument that francophones are not at all ‘dead ducks’ outside of Québec.

An equally persuasive argument is offered by Michael O'Keefe, a manager in the federal department of Canadian Heritage's Official Languages Branch. Although not necessarily the most objective analyst, O'Keefe puts forth a number of interesting empirical arguments which demonstrate that francophone identities outside Québec are still robust. O’Keefe informs us that "school and community infrastructures that have been put in place during the past 25 years are having a measurable impact," ${ }^{, 69}$ and that "there are unmistakable signs of progress."70 The author also points to the fact that bilingualism is increasing rapidly among anglophones, and that "rising bilingualism of Anglophones within Canadian society may play an important role in strengthening minority language community vitality." ${ }^{, 1}$ Although the author is probably not a

\footnotetext{
${ }^{64}$ Ibid., 125. Translated by the author.

${ }^{65}$ Ibid., 128.

${ }^{66}$ Ibid., 121.

${ }^{67}$ Ibid., 131-4.

${ }^{68}$ Ibid., 138. Translated by the author.

${ }^{69}$ O’Keefe, 36.

${ }^{70}$ Ibid., 87.

${ }^{71}$ Ibid., 50.
} 
completely unbiased observer, the figures he cites are from census data supplied by Statistics Canada, which suggests the numbers he uses to back his claims must be taken seriously.

While these observers have suggested that the identity of francophone minorities is stronger and less in danger than others have previously argued, they are equally enthusiastic about the role that statutory and constitutional language rights have played in the revitalization of this identity. Aunger argues that the minority language rights in the Charter are beginning to "bear fruit,"72 and, in relation to education rights, that "the Charter of Rights and Freedoms which has guaranteed instruction in French since 1982 and the schools that are managed by the francophone minority offer the possibility of addressing the wrongs of the past."73 Significantly, O’Keefe also quotes the findings of a study by Cardinal et. al., which indicates that francophone minorities have in many ways 'anchored' their identities in Charter language rights, particularly minority education rights, which they feel have potential to diminish many of the demographic obstacles that they face. ${ }^{74}$ This identification with Charter rights and their potential salutary effects is a major development for French Canadians which suggests that the language rights of the Charter have affected these identities in an important way.

While these more optimistic authors often make use of data from the 1996 census (which was in most cases the most recent census at the time of their writing), census data from 2001 confirm and strengthen the logic underlying their optimism in many cases. As is reported by Statistics Canada, the francophone minority population (by mother tongue) grew between 1996 and 2001 in Ontario, British Columbia, Alberta and Prince Edward Island, which includes

\footnotetext{
${ }^{72}$ Aunger (2002), 131. Translated by the author.

${ }^{73}$ Ibid., 130. Translated by the author.

${ }^{74}$ O’Keefe, 37-8.
} 
Canada's three largest majority anglophone provinces. ${ }^{75}$ The increase was spectacular in Alberta (a province "reputed for its conservatism and its opposition to the policy of bilingualism"76), where the increase was $12.6 \%$, with the addition of nearly 7000 people since the 1996 census. $^{77}$ Less positive but still encouraging for francophone minorities is the fact that in three other provinces, the rate of decline was lower between 1996 and 2001, than it was between 1991 and 1996, suggesting that the decline of minority francophone communities slowed during the latter half of the 1990s in these provinces. ${ }^{78}$ Overall, in Canada less Québec, while the francophone minority community declined by 0.6\% (about 6000 people) between 1991 and 1996, it grew by $1.0 \%$ the following five years (about 10000 people). ${ }^{79}$ Although its proportion of the Canadian population continues to decrease, as other linguistic groups are growing faster, an arresting of the trend of negative demographic growth, at least temporarily, is very encouraging for Canada's francophone minorities. ${ }^{80}$ Similar trends are seen for home language when individual provinces are examined, although French continues to lose ground as a language spoken at home generally in Canada, and in Canada less Québec. ${ }^{81}$

As Couture also illustrates, the rate of bilingualism in Canada is on the rise, increasing from $16.3 \%$ in 1991 , to $17.0 \%$ in 1996 , to $17.7 \%$ in $2001 .^{82}$ In addition, every province and territory (including Québec) except for Manitoba, Saskatchewan, the Yukon, and Nunavut registered increases in bilingualism between the 1996 and 2001 censuses. ${ }^{83}$ However, while the

\footnotetext{
${ }^{75}$ Canada. Statistics Canada. "Profile of Languages in Canada: English, French and Many Others." http://www12.statcan.ca/english/census01/Products/Analytic/companion/lang/contents.cfm (December 10, 2002)

${ }^{76}$ Couture, 11. Translated by the author.

77 Statistics Canada.

78 Ibid.

${ }^{79}$ Ibid.

${ }^{80}$ Ibid.

${ }^{81}$ Ibid. While French as a home language continues to grow in Ontario, British Columbia, and Alberta, it decreased in Canada as a whole, and in Canada less Québec.

${ }_{82}^{82}$ Ibid.

${ }^{83}$ Ibid.
} 
rate of bilingualism continues to grow outside of Québec, the national rate is significantly less high when Québec residents are excluded from the calculations, going from 9.8\% in 1991, to $10.2 \%$ in 1996 , to $10.3 \%$ in $2001 .^{84}$ As well, evidence suggests that while the national anglophone rate of bilingualization continues to increase, reaching $9.0 \%$ in 2001 , it still lags far behind that of francophones, of whom $43.4 \%$ are bilingual. ${ }^{85}$

Lastly, when Canada’s largest anglophone cities are examined, we see a number of metropolitan centres in which French is still very prominent. Sudbury is Canada’s Census Metropolitan Area (CMA) with the highest proportion of mother tongue francophones outside Québec, with an official language minority population of $28.9 \% .^{86}$ It is followed by Ottawa (the Ontario part of the CMA) in which $17.4 \%$ of residents are francophone. ${ }^{87}$ As well, Saint John, Winnipeg, Windsor, and St. Catharines-Niagara all have minority francophone populations approaching 5 per cent. ${ }^{88}$ This data indicates that there are significant francophone minority concentrations in several of Canada’s major anglophone urban centres, a key development for the future of Canada's francophone communities.

As data from the most recent census attests, Canada’s minority francophone identity seems to be strong nationally, and is gaining strength in a number of key areas, including Canada's three largest majority anglophone provinces. Combined with the optimistic arguments made by analysts such as O’Keefe, Aunger, and Couture, it appears that Canada’s francophone minority identity may not be as much in danger as was previously suggested by some scholars. As C. Michael MacMillan summarizes: "the francophone minorities have proved surprisingly

\footnotetext{
${ }^{84}$ Ibid.

${ }^{85}$ Ibid.

${ }^{86}$ Indeed, Sudbury is Canada's only CMA in which there are more francophones than allophones by mother tongue.

${ }^{87}$ Ibid.

${ }^{88}$ Ibid.
} 
resilient. ${ }^{„ 89}$ Although we must remember to be cautious about attributing this new vitality to language rights alone as several of these communities were very strong before the rights of the OLA and Charter were proclaimed, ${ }^{90}$ it is likely that language rights have had some impact and have empowered their bearers with new confidence. ${ }^{91}$

One of the most important effects that language rights have had is on French language education in majority anglophone provinces. Unlike the OLA, which applied solely to federal jurisdiction, the Charter applies to both federal and provincial jurisdiction, and obligates the provinces to provide official language minority education in accordance with rights contained in s. 23. However, many anglophone provinces were slow to establish the proper institutional base for French schools, in some cases relying on constitutional ambiguities to justify their refusal to spend the funds needed for proper French schools. As a result, a group of francophones from Edmonton sued the Alberta government, a case which was ultimately decided by the Supreme Court of Canada. In its judgement of Mahé v. Alberta [1990] 1 S.C.R. 342, the Supreme Court ruled in favour of the francophone group. In its first major opportunity to rule on s. 23 of the Charter, the Court adopted a liberal interpretation of the section, and "broadened the Charter right of francophone minorities to French schools to include the right to manage and control their own school boards. ${ }^{\text {} 92}$ Non only did this judgement force the Alberta government to act on French schooling, it also gave French Canadians more than what was originally granted in the text of s. 23 which has provided a significant advantage to these minority groups.

Official language minority education, which was strengthened by this judgement, has had

\footnotetext{
${ }^{89}$ C. Michael MacMillan. The Practice of Language Rights in Canada. (Toronto: University of Toronto Press, 1998), 223.

${ }^{90}$ Such as Alberta's St. Paul community which has had a strong francophone character for nearly a century. Aunger (1993).

${ }^{91}$ As is suggested in the study by Cardinal et. al., cited in O'Keefe, 37-8.

${ }^{92}$ Coloumbe, 129.
} 
important effects for Canada's francophones. We have already seen that O’Keefe and Aunger feel that schools are having an impact on the French Canadian community and identity. Likewise, Magnet suggests that schools have replaced Catholic parishes as the centre of cultural vitality and transmission for French Canadians in many communities. Noting that francophone schools are "the place where culture is passed on," 93 the Office of the Commissioner of Official Languages reports that there are over 160000 students in over 700 French schools in majority anglophone provinces. ${ }^{94}$ Indeed, there is even an interest group, Canadian Parents for French, which was set up specifically to lobby for bilingual and minority language schooling. ${ }^{95}$ This group, which receives the majority of its funding from the federal government, played an important role in having s. 23 entrenched in the Charter. ${ }^{96}$ Since the Mahé judgement, French language schooling for minorities has become an important element of French Canadian identity. French schooling has made an important contribution to the vitality of francophone minority identities which may be attributable to the Charter rights of s. 23.

In the post-Charter environment of increased accommodation of French Canadians outside of Québec, a number of provinces have granted additional statutory rights to their francophone minorities, which have also assisted French Canadian identities. The most farreaching protections of French minorities are found in New Brunswick, where the province passed its own OLA in 1969, which was similar to the federal Act. ${ }^{97}$ Similarly, in 1981, Bill 88 was passed by the New Brunswick government, which recognized the equality of the two official

\footnotetext{
${ }^{93}$ Office of the Commissioner of Official Languages, 14.

${ }^{94}$ Ibid., 15.

${ }^{95}$ Pal, Leslie A. Interests of State: The Politics of Language, Multiculturalism, and Feminism in Canada. (Montreal and Kingston: McGill-Queen’s University Press, 1993), 167-171.

${ }^{96}$ Ibid., 166-168.

${ }^{97}$ MacMillan, 139.
} 
language communities in the province. ${ }^{98}$ Finally, the New Brunswick government asked the federal government to entrench the language rights of ss. 16-20 of the Charter for its province as well, making it the first and only fully and constitutionally bilingual province in Canada. Other provinces have provided rights for their minorities as well, though not to the same extent as has New Brunswick. For example, Ontario’s French Language Services Act of 1986 provides services in French to francophones in twenty three districts of the province where there is a significant concentration of French speakers. ${ }^{99}$ Prince Edward Island has had an act of the same name since 2000 which serves a similar function. ${ }^{100}$ Several other anglophone provinces provide some French language services, such as health care and social services, though often due to the "heavy-prodding" and financial support of the federal government. ${ }^{101}$

A smaller statutory gain made by several OLMGs at the federal level relates to governance agreements signed with Ottawa in the 1990s. In the difficult financial climate of the early part of the decade, the federal government sought to download some of its responsibilities in the promotion of official languages. ${ }^{102}$ As a result, a number of OLMGs signed agreements with Ottawa from which they gained increased responsibility and funding from the federal government for the promotion of the objectives of the OLA. These agreements also resulted in a more stable financial arrangement, and a more coherent plan from Ottawa, in spite of the economic chaos in the government at the time. ${ }^{103}$ Francophone groups were among the principle beneficiaries of this devolution, which strengthened their finances and self-management abilities further.

\footnotetext{
${ }^{98}$ MacMillan, 142. Because of this law, there is no minority official language community in New Brunswick, simply two equal linguistic communities.

${ }^{99}$ Coloumbe, 99.

${ }^{100}$ Linda Cardinal, and Marie-Eve Hudon. Governance of Canada's Official Language Minorities: A Preliminary Study. (Ottawa: Minister of Public Works and Government Services Canada, 2001), 48.

${ }^{101}$ McRoberts, 97-98.

${ }^{102}$ Cardinal and Hudon, 9.

${ }^{103}$ Ibid., 13.
} 
Among the areas where French Canadians would be expected to benefit most from the language rights of the Charter and the OLA would be in the courts. We have already seen that they won an important victory in the Mahé case of 1990. However, French Canadians have not always won in the courtroom, with the first major Charter language rights precedent, $\underline{\text { Societé des }}$ Acadiens du Nouveau-Brunswick v. Parents for Fairness in Education [1986] 1 S.C.R. 549, being unfavourable for French Canadians. In this case, the Supreme Court decided that language rights are based on 'political compromise' and that the courts should therefore approach them with more restraint and deference to legislatures than they should with other rights. ${ }^{104}$ Similarly,

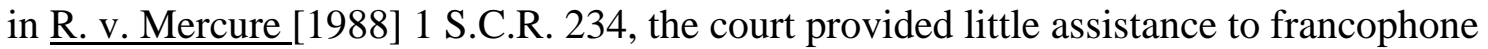
minorities in Alberta and Saskatchewan by ruling that the legislatures of those provinces could repeal official bilingualism if they chose to do so, which both did. ${ }^{105}$

However, with the Mahé precedent, the Court’s deferential outlook on language rights began to change. In addition, in 1999, the Supreme Court, with a number of new personnel since

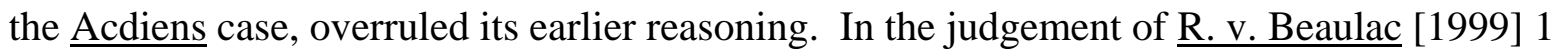
S.C.R. 768, speaking for the majority, Justice Michel Bastarache (an Acadian) stated: "there is no basis in the constitutional history of Canada for holding that...political compromises require a restrictive interpretation of constitutional guarantees.”106 Bastarache went further in ruling: "language rights must in all cases be interpreted purposively, in a manner consistent with the preservation and development of official language communities in Canada”"107 (emphasis in original). Since this landmark decision, in which the courts were ordered to be more activist and

\footnotetext{
104 MacMillan, 90.

${ }^{105}$ Ibid., 211. The Court decided similarly on a series of cases relating to bilingualism in Manitoba. Although the issues were different and much more complicated, the judgements amounted to the same result for French Canadians in Manitoba.

106 Para. 24.

107 Para. 25.
} 
generous in their interpretation of language rights, OLMGs have found the courts to be much more hospitable to their language rights, which has strengthened the rights of the OLMGs significantly. With this reinforcement of their language rights, the francophone minority identity is accorded further protection from the assimilating pressures that it faces.

Although not everyone agrees, ${ }^{108}$ the francophone minority identity in Canada has likely been positively affected by language rights, both statutory and constitutional. As census data and a number of authors demonstrate, the demographics of francophone minority communities have improved somewhat in recent years, while the institutional, legal, and funding arrangements of these groups have all improved as well. Therefore, while its advocates can not yet be rest easily, the future of the minority French Canadian identity is, for the time being, slightly less dreary than it has been in the past.

\section{Concluding Thoughts: The Future of Canada's Francophone Minorities}

While the future of French Canada is somewhat more secure now than it has been in the past, there is certainly no room for complacency, particularly with language issues in the constitution still very much undecided, and with the birthrate of non-Québec francophones being the lowest of any language group in Canada at 1.57 children per mother. ${ }^{109}$ Therefore, French Canada must adopt a number of strategies to ensure the continued survival of its identity in the future.

One obvious strategy that non-Québec francophones could adopt is to continue to press governments and the courts for increased services in French, and to further language rights with more favourable court decisions in the wake of the Beaulac precedent. An example from Ontario illustrates well how this strategy can be used. In the 1990s, while making major cutbacks to Ontario health care institutions, the Conservative government proposed the closing of the

\footnotetext{
108 See McRoberts, 105.

109 O’Keefe, 66-7.
} 
Montfort hospital and medical training facility, which is a franco-Ontarian institution in the Ottawa area. The government suggested that health services could be received by francophones more economically at a bilingual hospital nearby. As a result of furious political demonstrations, the government opted only to cut-back the services offered by the hospital. However, members of the francophone minority community sued the Ontario government, claiming that the government's decision to reduce the Montfort's services violated their right to respect as a minority, which was one of the four foundational principles of the constitution outlined by the Supreme Court in its decision in Reference Re: Secession of Quebec [1998] 2. S.C.R. 217.

In the case deciding this contentious health care issue, the Ontario divisional court sided with the francophone group, finding that their rights under the Secession Reference had indeed been violated. ${ }^{110}$ The Ontario Court of Appeal confirmed this judgement. With two court decisions against it, and continuing political pressure from francophone groups across the province, the Ontario government decided in 2002 not to appeal the decision to the Supreme Court, and agreed to keep the Montfort hospital open at full capacity. As this case study exemplifies, francophone minorities can make use of political pressure and litigation to defend themselves from pressure from the majority community, and secure the institutions and language rights that help maintain their identity. This strategy could be employed in a number of other provinces to push for the expansion of government services such as health care and social services.

Another strategy that French Canadians can use is to attempt to attract more immigrants into their communities, and to better integrate those who do come to them. These communities can mitigate the threat of assimilation posed by the trend of demographic decline by capitalizing on the large number of immigrants that enter into Canada from French speaking countries each

\footnotetext{
${ }^{110}$ Lalonde c. Ontario (Commission de restructuration des services de santé) 181, D.L.R. ( $\left.{ }^{\text {th }}\right) 263$.
} 
year. However, within some francophone communities, there is sometimes a degree of reticence about being open to new people who are born outside Canada. As many immigrant French speakers have different accents (often a more 'international' dialect of French) ${ }^{111}$ experiences, and contributions to make, they bring a very different element to the French Canadian identity. ${ }^{112}$ These differences have been the source of discomfort for some francophones, who have had difficulty adjusting to the addition of new elements to their collective identity which has been very similar for decades.

As Carston Quell suggests, however, the very purpose of the OLA in 1969 was not to generate exclusive linguistic communities, but rather, to bind individuals of different backgrounds (and geographic location, especially, province) by the language that they speak. ${ }^{113}$ As such, Quell recommends an increased openness to these new francophones on the part of French Canadians, in order to generate bonds with newcomers along linguistic lines, rather than ethno-cultural lines. While most francophone immigrants to Canada settle in the majority francophone society in Québec, 13.4\% choose to settle in Ontario, 4\% in British Columbia, and 1.4\% among the Acadians in New Brunswick. ${ }^{114}$ Capitalizing on these new French speaking individuals from Belgium, Lebanon, Bulgaria, Algeria, and numerous other countries in Asia, Europe and Africa ${ }^{115}$ would certainly bring a new element to the French Canadian identity, but would allow the identity to survive, and continue to function and thrive, and could compliment the traditional levers of language rights and government support to ensure the continued survival of francophone minority communities.

\footnotetext{
${ }^{111}$ Quell, 20.

112 Ibid., 18.

113 Ibid., 8.

114 Jack Jedwab. Immigration and the Vitality of Canada’s Official Language Communities: Policy, Demography and Identity. (Hull, Québec: Minister of Public Works and Government Services, 2002), 23.

115 Ibid., 27.
} 
A final strategy that could be employed by francophone groups relates to networking among French speaking groups in Canada. Increasing contact and communication between francophones in Québec, the bilingual belt, and outside the rest of Canada would allow for all French speaking Canadians to continue to function in French, while exposing these groups to the differing ways that French is a part of daily life in Canada. Ending some of the antipathy that developed in the past between the Québecois and non-Québec francophones would be a critical and necessary first step in this process. ${ }^{116}$ Such a strategy could involve the federal government taking the initiative in improving cultural exchange and communication infrastructure between French speaking groups across the country. ${ }^{117}$ For example, the federal government could create a programme which provides for exchanges between the Université de Montréal, the Université d'Ottawa, and the University of Alberta's Faculté Saint-Jean. Improving links and networks between Canada's various French speaking groups would allow members of these groups to live more of their lives in French, which would leave them less prone to assimilation, and more confident in the survival of their identity and community. With this increased confidence, and more opportunities to work, socialize, and learn in French, the French Canadian identity could be strengthened significantly.

While the identity of French Canadians in Canada has evolved a great deal, at the beginning of the twenty-first century, proponents of this still threatened identity may have reason to be optimistic. Although French Canadian minorities have endured many setbacks, and injustices at the hands of their English neighbours, there appears to be increased respect both for their language rights, and their identities. With continued vigilance, resilience, and protection from their hard-won language rights, it is possible that francophone minorities in Canada will not

\footnotetext{
${ }^{116}$ Cardinal, 81.

${ }^{117}$ Louis Balthazar. "History and Language Policy,” in David Schneiderman (ed.) Language and the State, the Law and Politics of Identity. (Cowansville, Québec. Les Editions Yvon Blais, 1991), 88.
} 
fall victim to assimilation, and that their identity will continue to form a strong element of the Canadian social fabric in the future.

\section{Bibliography}

\section{Books and Articles}

Abu-Laban, Yasmeen, and Tim Nieguth. "Reconsidering the Constitution, Minorities and Politics in Canada.” Canadian Journal of Political Science, 33(3) (2000), 465-497.

Aunger, Edmund A. "The Decline of a French-Speaking Enclave: A Case Study of Social Contact and Language Shift in Alberta.” Canadian Ethnic Studies 25 (2) (1993), 65-84.

Aunger, E.A. "Justifying the End of Official Bilingualism: Canada’s NorthWest Assembly and the Dual Language Question, 1889-1892.” Canadian Journal of Political Science, 36 (2001), 451.

Aunger, Edmund A. "Obseques Prematurees: La Disparation des Minorites Francophones et Autres Illusions nationalistes.” Review of Constitutional Studies. Vol. 7, nos. 1 \& 2 (2002), 120-142.

Balthazar, Louis. "History and Language Policy,” in David Schneiderman (ed.) Language and the State, the Law and Politics of Identity. Cowansville, Québec. Les Editions Yvon Blais, 1991.

Canada: Office of the Commissioner of Official Languages. Our Official Languages: As Century Ends and a Millennium Begins. Ottawa: Minister of Public Works and Government Services Canada, 2001.

Cardinal, Linda. "Linguistic Rights, Minority Rights and National Rights: Some Clarifications." Inroads, Vol. no. 8 (1999), 77-86.

Cardinal, Linda, and Marie-Eve Hudon. Governance of Canada's Official Language Minorities: A Preliminary Study. Ottawa: Minister of Public Works and Government Services Canada, 2001.

Castonguay, Charles. Getting the Facts Straight on French: Reflections Following the 1996 Census.” Inroads, Vol. no. 8 (1999), 57-76.

Coulombe, Pierre A. Language Rights in French Canada. New York: Peter Language Publishing Inc., 1997.

Couture, Claude. “La Disparition Inevitable des Francophone a l'Exterieur du Québec: Un Fait 
Ineluctable ou le Reflet d'un Discours Deterministe?” Francophonie d'Amerique. no 11 (2001), 7-17.

Couture, Claude, and Denis Perreaux. "La Resistance des Francophones des Prairies L'assimilation dnas la perspective de la literature moderniste et Postcoloniale." Francophonie d'Amerique. no 13 (2002), 199-209.

Denis, Wilfred. "Language Policy in Canada," in Peter S. Li (ed.) Race and Ethnic Relations in Canada. Second Edition. Don Mills, Ontario: Oxford University Press, 1999, 178-216.

Jedwab, Jack. Immigration and the Vitality of Canada’s Official Language Communities: Policy, Demography and Identity. Hull, Québec: Minister of Public Works and Government Services, 2002.

Joy, Richard. Canada's Official Language: The Progress of Bilingualism. Toronto: University of Toronto Press, 1992.

MacMillan, C. Michael. The Practice of Language Rights in Canada. Toronto: University of Toronto Press, 1998.

Magnet, Joseph Elliot. Official Languages of Canada: Perspectives from Law, Policy and the Future. Cowansville, Québec. Les Editions Yvon Blais, 1995.

McRoberts, Kenneth. Misconceiving Canada: The Struggle for National Unity. Toronto: Oxford University Press, 1997.

Morton, F.L., and Rainer Knopff. The Charter Revolution and the Court Party. Peterborough: Broadview Press, 2000.

O’Keefe, Michael. Francophone Minorities: Assimilation and Community Vitality. Second Edition. Hull, Québec: Department of Canadian Heritage, 2001.

Pal, Leslie A. Interests of State: The Politics of Language, Multiculturalism, and Feminism in Canada. Montreal and Kingston: McGill-Queen’s University Press, 1993.

Quell, Carsten. "Racial, Religious, Ethnic and Linguistic Diversity Intersecting with Canadian Official Language Policies and Communities.” Unpublished (Draft of Paper to be presented at Intersections of Diversity Seminar, Niagara Falls, Ontario, April, 2003).

Smith, Miriam. "Social Movements and Equality Seeking: The Case of Gay Liberation in Canada.” Canadian Journal of Political Science, 31(2) (1998), 286-309.

Stebbins, Robert A. The French Enigma: Survival and Development in Canada's Francophone Societies. Calgary: Detselig Enterprises Ltd., 2000. 


\section{Websites}

Canada. Statistics Canada. "Profile of Languages in Canada: English, French and Many Others.” http://www12.statcan.ca/english/census01/Products/Analytic/companion/lang/contents.cfm (December 10, 2002)

\section{Cases}

Lalonde v. Ontario (Commission de restructuration des services de santé), [1999]. 181, D.L.R. (4th) 263.

Mahé v. Alberta [1990] 1 S.C.R. 342.

R. v. Beaulac, [1999] 1 S.C.R. 768.

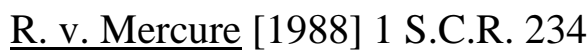

Reference re: Secession of Quebec, [1998] 2 SCR 217.

Société des Acadiens du Nouveau-Brunswick c. Parents for Fairness in Education, [1986] 1 S.C.R. 549. 